Irina Gavrash

Instytut Historii Sztuki, Uniwersytet Gdański

ORCID: 0000-0001-9026-6782

\title{
Wystawa „100 lat realizmu w sztuce polskiej” w Akademii Sztuk Pięknych ZSRR w Moskwie (1952) w kontekście polsko-radzieckich stosunków kulturalnych w latach 1949-1955
}

\author{
DOI: https://doi.org/10.26881/porta.2018.17.07
}

Formalno-prawny aspekt stosunków polsko-radzieckich po drugiej wojnie światowej został określony w Układzie o przyjaźni, pomocy wzajemnej i współpracy powojennej, podpisanym 21 kwietnia 1945 r. ${ }^{1}$ Hasła przyjaźni i współpracy miały oczywiście charakter fasadowy, w istocie bowiem Związek Radziecki, dysponując znacznym potencjałem militarnym, dążył do zapewnienia sobie dominującej pozycji w zdobytym obszarze wpływów. W Polsce, tak jak w innych krajach, które znalazły się $\mathrm{w}$ tej strefie, wzory radzieckie przyjmowano we wszystkich dziedzinach życia, w tym również w kulturze traktowanej jako jedno z narzędzi kształtowania pożądanej postawy ideowo-politycznej społeczeństwa i z tego też powodu otoczonej szczególną „opieką” partyjną.

Instrumentem, dzięki któremu strona radziecka mogła efektywnie wpływać na kształt kultury i sztuki polskiej, był sprawnie działający system wymiany kulturalnej. Istotną rolę w tym zakresie odgrywało powstałe w $1927 \mathrm{r}$. Wszechzwiązkowe Towarzystwo Łączności Kulturalnej z Zagranicą (Wsiesojuznoje Obszcziestwo Kulturnych Swiaziej - WOKS) ${ }^{2}$. W Polsce na wzór radzieckiej instytucji powołany został, na mocy ustawy o organizacji wymiany kulturalnej z zagranicą z 18 lipca 1950 r., Komitet Współpracy Kulturalnej z Zagranicą [dalej: KWKZ] przy Prezydium Rady Ministrów RP ${ }^{3}$. Instytucja ta, utworzona w ramach centralizacji życia kulturalnego, miała zastąpić jednostki o podobnym charakterze $w$ ministerstwach oraz urzędach centralnych i im podległych

1 Układ o przyjaźni, pomocy wzajemnej i współpracy powojennej między Związkiem Socjalistycznych Republik Radzieckich i Rzeczpospolitą Polską, 19.09.1945, Dz. U. 1945, nr 47, poz. 268, http://prawo.sejm.gov.pl/isap.nsf/DocDetails.xsp?id=WDU19450470268 [dostęp: 25.08.2018].

2 Mirosław Golon, Między stalinowska propaganda a upowszechnianiem kultury. Działalność Wszechzwiązkowego Towarzystwa Łączności Kulturalnej z Zagranica (WOKS) wobec Polski w latach 1945-1956, „Dzieje Najnowsze” 2006, R. 37, nr 4, s. 123-145.

3 Ustawa z dn. 18.07.1950 o organizacji współpracy kulturalnej z zagranicą, Dz. U. 1950, nr 36, poz. 324, http://prawo.sejm.gov.pl/isap.nsf/DocDetails.xsp?id=WDU19500360324 [dostęp: 25.08.2018]. 
w zakresie „planowania, popierania i utrzymywania stosunków kulturalnych z innymi narodami” (z wyjątkiem Ministerstwa Spraw Zagranicznych) ${ }^{4}$.

W pierwszych latach powojennych Polska, choć czyniła stosowne starania, nie miała umowy, która regulowałaby wymianę kulturalną z ZSRR. Wobec tego na podstawie zgłaszanych przez poszczególne resorty propozycji KWKZ opracowywał roczne plany wymiany kulturalnej, przedkładane do akceptacji przez instytucje polskie oraz stronę radziecką. Brak regulacji formalnych świadczył o dalekich od partnerskich stosunkach pomiędzy obydwoma krajami, co przejawiało się chociażby w znaczącej przewadze imprez radzieckich w Polsce.

Kontakty artystyczne stanowiły jedną z dziedzin wymiany kulturalnej. Wskazany $\mathrm{w}$ tytule okres wiązał się z panowaniem w PRL-u doktryny realizmu socjalistycznego ${ }^{5}$, kiedy to organizacja życia artystycznego w ZSRR najsilniej odcisnęła swoje piętno na polskiej sztuce. Jednym z narzędzi służących do transponowania wzorców radzieckich w obrębie plastyki były wystawy. Relacja zwrotna polegała zaś na „weryfikacji” osiągnięć twórców polskich przez stronę radziecką, co w praktyce odbiegało jednak od założeń, ujawniając zarówno napięcia o podłożu politycznym, jak i rozbieżności w zakresie pojmowania funkcji sztuki. Problemy te ogniskowała również ekspozycja „100 lat realizmu w sztuce polskiej” (17 maja - 16 czerwca 1952 r.), zaprezentowana w Akademii Sztuk Pięknych w Moskwie .

Wystawę obejmującą sztukę polską drugiej połowy XIX w. oraz współczesną sztukę socrealistyczną przygotowano w ramach planu wymiany kulturalnej z ZSRR na rok $1952^{7}$. Została ona zorganizowana staraniem KWKZ oraz Ministerstwa Kultury i Sztuki. W jej realizację były także zaangażowane Centralne Biuro Wystaw Artystycznych oraz Muzeum Narodowe w Warszawie 8 .

Ekspozycja została uroczyście otwarta 17 maja. Na inauguracji kolejno zabierali głos: wiceprzewodniczący Akademii Sztuk Pięknych ZSRR, rzeźbiarz Matwiej Manizer, zastępca wiceprzewodniczącego Komitetu do Spraw Sztuki przy Radzie Ministrów ZSRR Michaił Czułaki, a także prezydent Akademii Aleksander Gierasimow. Ze strony polskiej mowy wygłosili: Radca Ambasady PRL w Moskwie Leonard Pohoryles oraz przybyli na tę okoliczność wraz z delegacją artystów polskich wiceminister w Ministerstwie Kultury i Sztuki

4 Szczególną wagę w zakresie działalności KWKZ przywiązywano do wymiany kulturalnej ze Związkiem Radzieckim, o czym świadczy struktura organizacji Biura Komitetu, w ramach której powołano osobny Wydział Współpracy Kulturalnej z ZSRR.

5 Wojciech Włodarczyk, Socrealizm. Sztuka polska 1950-1954, Kraków 1991; Игорь Голомшток, Тоталитарное искусство, Москва 1994; Wojciech Włodarczyk, Socrealistyczny epizod [w:] Warszawa-Moskwa / Москва-Варшава. 1900-2000 [katalog wystawy], red. Maria Poprzęcka, Lidja Jowlewa Narodowa Galeria Sztuki „Zachęta”, Warszawa 2005, s. 63-69.

6 Zob. Polskie życie artystyczne w latach 1944-1960, t. 6, Rok 1952, red. Anna Wierzbicka, Warszawa 2015, s. 200-201. Ekspozycja została pokazana także w Muzeum Narodowym w Warszawie (21.07-07.08.1952), zob. ibidem, s. 126-127.

7 Archiwum Akt Nowych, KWKZ, sygn. 56, Plan wymiany kulturalnej polsko-radzieckiej [na 1952 r.], k. 120.

8 Archiwum Muzeum Narodowego w Warszawie, sygn. 1158. 
Irina Gavrash

Władysław Sokorski i rektor warszawskiej Akademii Sztuk Pięknych Marian Wnuk ${ }^{9}$. Na otwarciu byli obecni również prominentni przedstawiciele świata artystycznego, a wśród nich malarze: Boris Joganson, Piotr Konczałowski, Dmitrij Nałbandian, oraz rzeźbiarka Wiera Muchina. Po uroczystości oficjalnej w salonach Akademii zorganizowano przyjęcie dla gości ${ }^{10}$.

Według informacji Ambasady PRL w Moskwie wystawa sztuki polskiej była oczekiwanym wydarzeniem zarówno w środowisku artystycznym, jak i wśród społeczeństwa radzieckiego. Ekspozycję zwiedziło 13000 osób, w tym około 100 wycieczek zbiorowych. Do oprowadzania po wystawie wyszkolono zespół przewodników, dla których kustosz wystawy Jerzy Zanoziński wygłosił wykłady o malarstwie polskim ${ }^{11}$.

Wystawa została podzielona na dwa działy ${ }^{12}$. Pierwszy obejmował sztukę polską drugiej połowy XIX i początków XX w., drugi był poświęcony twórczości współczesnej. W części retrospektywnej pokazano 94 prace malarskie, 51 grafik, 12 rzeźb, część druga składała się z 34 obrazów i 6 rzeźb współczesnych. Z powyższego zestawienia wynika, że akcent został postawiony na sztukę dawną, która stanowiła 3/4 ogółu dzieł. W obydwu działach dokonano wyboru obiektów, wyraźnie faworyzując malarstwo. Liczbę eksponatów rzeźbiarskich ograniczono ze względu na trudności związane z transportem. Z kolei zaprezentowana na wystawie niewielka liczba rysunków oraz akwareli dziewiętnastowiecznych świadczyła o tym, że prace te potraktowano jako mniej znaczące niż dzieła malarskie - miały one jedynie przybliżyć warsztat artystów. Zupełnie zrezygnowano z prezentowania grafiki współczesnej, tłumacząc, iż jest to zjawisko tak rozległe, że wymagałoby zorganizowania oddzielnej wystawy ${ }^{13}$.

9 Archiwum Ministerstwa Spraw Zagranicznych [dalej: AMSZ], Departament 1., Wydział Radziecki, w. 4, t. 32, Raport Ambasady PRL w Moskwie za miesiąc maj 1952 r., k. 204-205.

10 AMSZ, Departament 1., Wydział Radziecki, w. 4, t. 32, Raport Ambasady PRL w Moskwie za miesiąc maj 1952 r., k. 205.

11 AMSZ, Departament 1., Wydział Radziecki, w. 4, t. 32, Raport Ambasady PRL w Moskwie za miesiąc czerwiec 1952 r., k. 238.

12 Wystawie głównej towarzyszył pokaz plakatu polskiego, pomyślany jako osobna ekspozycja obejmująca około stu eksponatów o tematyce przeważnie propagandowej, ale także filmowej i teatralnej. Inauguracja wydarzenia miała miejsce 10 czerwca w sali wystawowej Związku Plastyków Radzieckich. W odróżnieniu od ekspozycji plastyki polskiej pokaz plakatu spotkał się z jednoznacznie przychylnym przyjęciem publiczności radzieckiej, o czym może świadczyć uroczysta oprawa otwarcia drugorzędnej w zasadzie ekspozycji, nagłaśnianie przemówień w radiu, promocja pokazu za pomocą plakatów w przestrzeni miejskiej, a także liczne anonse w prasie. O powodzeniu przesądziły zapewne przewaga politycznych akcentów oraz użytkowy charakter sztuki dopuszczający większy zakres swobody formalnej. Wydano osobny katalog, zob. Филиал выставки польского изобразительного искусства. Плакат [katalog wystawy], Москва 1952. Zob. także: Polskie życie artystyczne..., s. 202; AMSZ, Departament 1., Wydział Radziecki, w. 4, t. 32, Raport Ambasady PRL w Moskwie za miesiąc maj 1952 r., k. 206; AMSZ, Departament 1., Wydział Radziecki, w. 4, t. 32, Raport Ambasady PRL w Moskwie za miesiąc czerwiec 1952 r., k. 239.

13 Jerzy Zanoziński, Pokłosie wystawy plastyki polskiej w Moskwie, „Przegląd Artystyczny” 1952, nr 4, s. 43. Później jednak uznano tę decyzję za chybioną, głównie z powodu negatywnej oceny działu współczesnego przez stronę radziecką - uznano, że prezentacja grafiki polskiej 
Prace pokazane w dziale retrospektywnym pochodziły ze zbiorów Muzeum Narodowego w Warszawie, Krakowie i Poznaniu, Muzeum Sztuki w Łodzi, Muzeum Śląskiego we Wrocławiu, Muzeum Górnośląskiego w Bytomiu oraz Uniwersytetu Jagiellońskiego w Krakowie. Kilka obiektów wypożyczono z kolekcji prywatnych w Warszawie i Krakowie. Dzieła współczesne zostały wyselekcjonowane z prac prezentowanych na I i II Ogólnopolskiej Wystawie Plastyki $(1950,1951)^{14}$, a także na wystawie „Plastycy w walce o pokój” $(1950)^{15}$.

Wydawnictwo Akademii Sztuk Pięknych ZSRR („Sowietskij Chudożnik”) wydało - na podstawie materiałów nadesłanych przez stronę polską - katalog wystawy ze wstępem autorstwa wiceministra Sokorskiego oraz komisarza wystawy Zanozińskiego, kustosza Muzeum Narodowego w Warszawie ${ }^{16}$. Słowa pierwszego dotyczyły okoliczności wprowadzenia w Polsce socrealizmu. Sokorski wskazywał także etapy, które musiała przejść po wojnie sztuka polska, aby przyswoić sobie doświadczenia radzieckie, kontynuując jednocześnie tradycje sztuki narodowej ${ }^{17}$. Punktami węzłowymi, mającymi mobilizować plastyków do pracy oraz dającymi możliwość przeglądu dokonań artystycznych, a co ważniejsze - korygowania wyników pracy twórczej, były wystawy tematyczne poświęcone istotnym zagadnieniom związanym $\mathrm{z}$ rozwojem socjalizmu oraz doroczne Ogólnopolskie Wystawy Plastyki, wzorowane na Wszechzwiązkowych Wystawach Plastyki w ZSRR. Wystawa sztuki polskiej w Moskwie miała więc stanowić kolejny etap - weryfikacji tej sztuki przez ostateczną instancję. Jednocześnie wiceminister Sokorski tłumaczył się z decyzji wystawienia na ekspozycji niedużej - w porównaniu do sztuki dawnej - liczby prac współczesnych, wskazując na wciąż obecne w twórczości artystów polskich niedociągnięcia, związane $\mathrm{z}$ trudnościami w opanowaniu warsztatu realistycznego. Być może próbował w ten sposób uprzedzić ewentualne ataki ze strony radzieckiej. Natomiast tekst Zanozińskiego poświęcony był omówieniu historii malarstwa polskiego drugiej połowy XIX w. oraz początkom malarstwa socrealistycznego ${ }^{18}$. Decyzja o zorganizowaniu wystawy prezentującej zarówno polską sztukę dziewiętnastowieczną, jak i współczesną sztukę ostatnich lat wynikała z zamiaru ukazania w ciągu rozwojowym tendencji realistycznych ubiegłego wieku oraz kontynuujących je niejako tendencji współczesnej sztuki realistycznej w oficjalnym wydaniu socrealistycznym.

mogłaby ją nieco skorygować. Również we wpisach do księgi pamiątkowej pojawiały się głosy wyrażające żal z powodu braku prac graficznych na ekspozycji, zob. AMSZ, Departament 1., Wydział Radziecki, w. 4, t. 32, Raport Ambasady PRL w Moskwie za miesiąc czerwiec 1952 r., k. 258.

14 I Ogólnopolska Wystawa Plastyki [katalog wystawy], Muzeum Narodowe w Warszawie, Warszawa 1950; II Ogólnopolska Wystawa Plastyki [katalog wystawy], Centralne Biuro Wystaw Artystycznych „Zachęta”, Warszawa 1951.

${ }_{15}$ Ogólnopolska Wystawa „Plastycy w walce o pokój” [katalog wystawy], Centralne Biuro Wystaw Artystycznych „Zachęta”, Warszawa 1950; Zanoziński, Pokłosie..., s. 43.

16 Выставка польского изобразительного искусства [katalog wystawy], Москва 1952.

17 Влодзимеж Сокорский [w:] Выставка..., s. 4-5.

18 Ежи Занозиньский, Выставка польского искусства [w:] Выставка..., s. 6-17. 
Irina Gavrash

Warto w tym kontekście przywołać dwie fotografie ukazujące fragmenty ekspozycji - działu dawnego i malarstwa współczesnego, ilustrujące poświęcony recepcji wystawy w Moskwie artykuł Zanozińskiego opublikowany w „Przeglądzie Artystycznym"19. W obu wypadkach rzeźba - choć nielicznie reprezentowana w Moskwie - została potraktowana jako element organizujący kompozycję zdjęć oraz ich warstwę semantyczną. Na pierwszej fotografii (il. 1), po lewej stronie, zostało ujęte popiersie Adama Mickiewicza autorstwa Marcelego Gujskiego na tle rodzajowych kompozycji Aleksandra Kotsisa. Kolejną fotografię (il. 2) zakomponowano na zasadzie lustrzanego odbicia. Tym razem rzeźba przedstawiająca głowę Lenina została ukazana po przeciwnej stronie, w prawej części zdjęcia. Za nią, w głębi sali, widnieją kolejno obrazy: Lenin w Poroninie Wojciecha Fangora, Dzierżyński w drodze na Syberię oraz Podaj cegłę Aleksandra Kobzdeja, a także Manifest Wojciecha Weissa. W jednym i drugim wypadku w kadrze znalazły się rzeźbiarskie reprezentacje postaci kluczowych zarówno dla dziewiętnastowiecznej martyrologii narodowej, jak i współczesnej mitologii socjalistycznej. Połączenie pomnika Mickiewicza z obrazami przedstawiającymi sceny rodzajowe z życia wsi polskiej zespalało sprawy narodowo-wyzwoleńcze z problemami klasowymi. Intencja ta była czytelna na poziomie dyskursu obudowującego wystawę (np. tekstów zamieszczonych w katalogu), tworząc ramę interpretacyjną dla sztuki dawnej.

Sztukę XIX w. reprezentowały dzieła malarzy historycznych, uwikłanych w powinności narodowe, takich jak Henryk Rodakowski (Portret Generała Dembińskiego, 1852), Jan Matejko (m.in. Stańczyk, szkic, 1862; Kazanie Skargi, 1864), Artur Grottger czy Jacek Malczewski (sceny z życia zesłańców polskich, m.in. Śmierć na etapie, 1891). Nie zabrakło też przedstawicieli malarstwa rodzajowo-pejzażowego, urodzonych w latach trzydziestych XIX w. - Wojciecha Gersona, Józefa Szermentowskiego, Aleksandra Kotsisa (porównywanych do "pieriedwiżników” rosyjskich) czy należących już do kolejnej generacji braci Maksymiliana i Aleksandra Gierymskich (m.in. Żydówka z cytrynami, 1881) oraz Józefa Chełmońskiego (m.in. Babie lato, 1875).

Doktryna socrealistyczna wybiórczo traktowała tradycję artystyczną, wydobywając jedynie te elementy, które dało się podciągnąć pod takie kategorie, jak „,realistyczny sposób przedstawiania”, „czytelność”, „narodowy charakter”, „zaangażowanie po stronie sił postępowych”. Ta siatka pojęć, formatująca twórczość artystyczną zgodnie z obowiązująca ideologią, zaważyła również na doborze dzieł prezentowanych na wystawie czy raczej świadomym pomijaniu obszarów niewygodnych. Jednak stopień realizacji postulatów ideowych przez organizatorów wystawy niuansował nieco ten sztywny schemat, już chociażby przez sam fakt włączenia do ekspozycji sztuki przełomu wieków, wkraczającej przecież w krąg problematyki modernistycznej. Mimo wyczuwalnych akcentów formalnych twórczość ta została potraktowana jako ostatnie ogniwo łączące

9 Zanoziński, Pokłosie..., s. 43-46. 


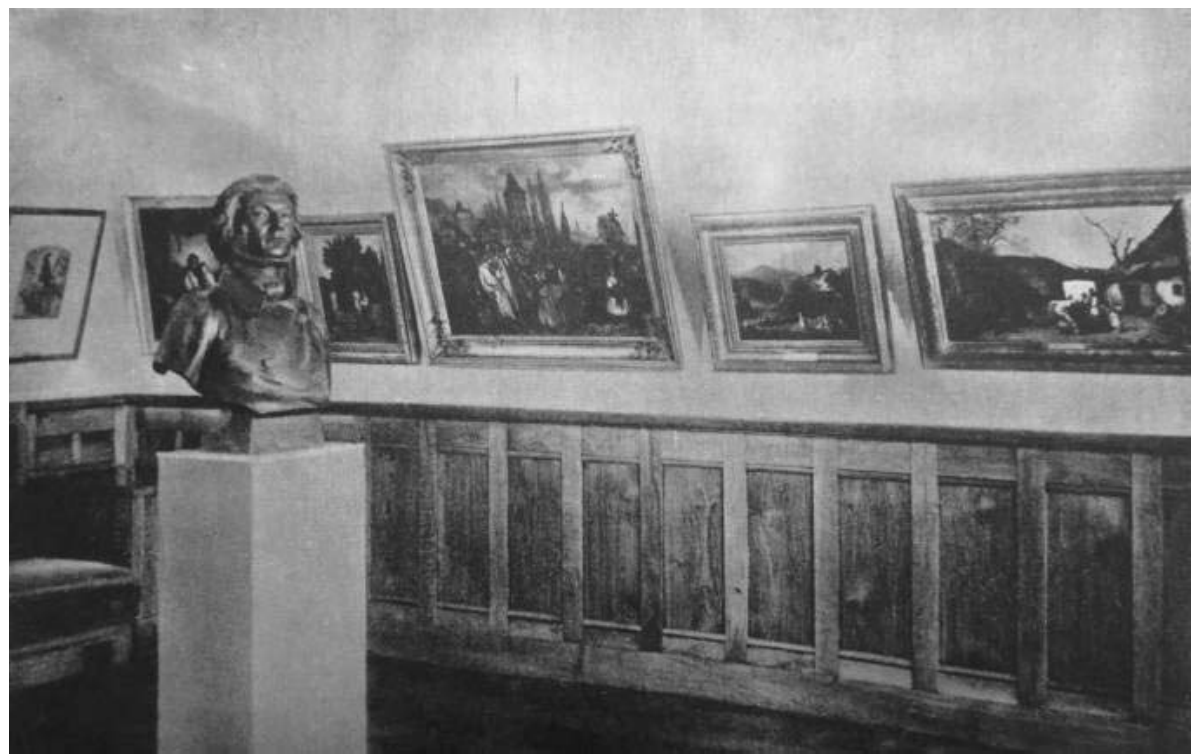

Il. 1. Fragment ekspozycji „100 lat realizmu w sztuce polskiej” w Akademii Sztuk Pięknych ZSRR w Moskwie, 1952, repr. za: Jerzy Zanoziński, Pokłosie wystawy plastyki polskiej w Moskwie, „Przegląd Artystyczny” 1952, nr 4, s. 44

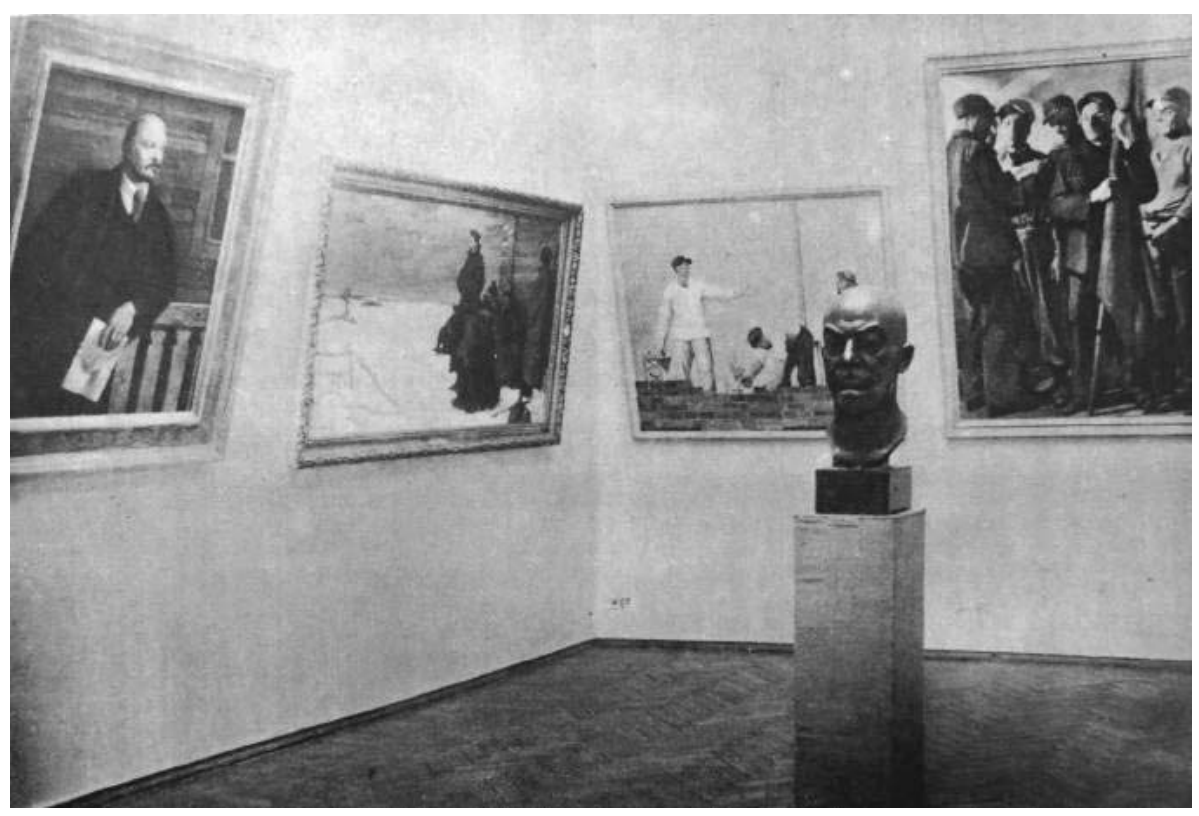

Il. 2. Fragment ekspozycji „100 lat realizmu w sztuce polskiej” w Akademii Sztuk Pięknych ZSRR w Moskwie, 1952, repr. za: Jerzy Zanoziński, Pokłosie wystawy plastyki polskiej w Moskwie, „Przegląd Artystyczny” 1952, nr 4, s. 45 
Irina Gavrash

tendencje realistyczne XIX w. i sztukę socrealistyczną. Zanoziński udowadniał zasadność przyjętej optyki w następujący sposób: „Polska sztuka realistyczna, którą cechuje zrozumienie społecznych i wychowawczych zadań sztuki, przeżywała swój kryzys na przełomie XIX i XX w. Polski kapitalizm wkraczał w stadium imperializmu. $\mathrm{W}$ obszarze sztuki proces ten związany był ze wzmocnieniem wpływów zachodnioeuropejskich. [...] Polscy twórcy początku XX w. częściowo ulegali wpływom impresjonizmu, zachowując jednak, w większej mierze niż to miało miejsce u artystów zachodnioeuropejskich, wierność tematyce życiowej"20.

Wystawa wywołała rezonans w środowisku radzieckich krytyków i artystów. Oprócz recenzji Aleksandra Tichomirowa (przedrukowanej w „Przeglądzie Artystycznym"21) obszerne omówienia wydarzenia zamieściły dzienniki „Komsomolskaja Prawda”, „Wieczernaja Moskwa”, „Sowietskoje Iskusstwo” oraz „Izwiestija”22. Zapowiadano, że polskiej sztuce poświęcony zostanie osobny numer czasopisma „Ogoniok”, w którym miały się ukazać kolorowe reprodukcje $^{23}$. Fragmenty wypowiedzi krytyków radzieckich wraz z cytatami wpisów do księgi pamiątkowej ${ }^{24}$ zostały przytoczone przez Zanozińskiego w omówieniu recepcji wystawy zamieszczonym w „Przeglądzie Artystycznym”25.

Na ogół reakcja krytyki radzieckiej wobec polskiego malarstwa dziewiętnastowiecznego była pozytywna, aczkolwiek jednostronna. Głównym kryterium stosowanym w ocenie tej twórczości było zaangażowanie artystów po stronie sił rewolucyjnych. Autor recenzji zamieszczonej w „Wieczernej Moskwie” konstatował: „Dawni artyści polscy nie odseparowywali się od życia narodu, od jego walki o lepszą przyszłość. Na wystawie oglądamy szereg obrazów, w których ostro zostały pokazane problemy społeczne, w których lud - wiejska biedota i miejski proletariat - jest przeciwstawiony feudalnym i burżuazyjnym szczytom, w których jasno są wyrażone konflikty między biedakami a bogaczami, między postępowymi a reakcyjnymi elementami społeczeństwa dawnej Polski”26.

20 Ежи Занозиньский, Выставка польского искусства [w:] Выставка..., s. 14-15.

Aleksander Tichomirow, Wystawa sztuki polskiej, „Przegląd Artystyczny” 1952, nr 3, s. 7-14.

Zanoziński, Pokłosie..., s. 43.

3 AMSZ, Departament 1., Wydział Radziecki, w. 4, t. 32, Raport Ambasady PRL w Moskwie za miesiąc maj 1952 r., k. 238.

24 Przedruki wpisów do księgi pamiątkowej zostały uwzględnione w formie załącznika w Raporcie Ambasady PRL w Moskwie za miesiąc czerwiec 1952 r., przygotowanym dla MSZ na dowód dużego zainteresowania publiczności radzieckiej wystawą plastyki polskiej, zob. AMSZ, Departament 1., Wydział Radziecki, w. 4, t. 32, Raport Ambasady PRL w Moskwie za miesiąc czerwiec 1952 r., k. 249-262. Leonard Pohoryles, radca ambasady, informował o „gorących dyskusjach i sporach", które rozgorzały na stronicach księgi, zwłaszcza wokół współczesnego malarstwa polskiego, zob. AMSZ, Departament 1., Wydział Radziecki, w. 4, t. 32, Raport Ambasady PRL w Moskwie za miesiąc maj 1952 r., k. 206.

25 Zanoziński, Pokłosie..., s. 43.

26 „Вечерняя Москва” 1952, nr 129, cyt. za: Zanoziński, Pokłosie..., s. 44. 
Więcej wątpliwości budził dział współczesny. W recenzjach wyrażano aprobatę dla artystów polskich i ich starań czynionych w kierunku opanowania metody twórczej. Podkreślano jednocześnie braki warsztatowe oraz ciągłe tkwienie w starych nawykach „formalistycznych”. Recenzent „Komsomolskiej Prawdy” pisał: „Wystawa daje pojęcie o ogólnym kierunku współczesnej sztuki polskiej w zakresie malarstwa i rzeźby. Artyści polscy, zwracając się ku współczesnej tematyce, uczą się poznawać życie i stają się aktywnymi współtwórcami socjalizmu. Co prawda, niekiedy tworzą nieco schematycznie i powierzchownie, nie zmienia to jednak faktu, że sztuka ich stopniowo wyzwala się spod wpływów formalistycznych i dekadenckich, wkracza na drogę realizmu socjalistycznego"27.

Formalny podział ekspozycji na dwa działy ulokowane w osobnych salach oraz formuła wystawy zakładająca ukazanie ciągłości nurtu realistycznego w sztuce polskiej narzucały oczywiście konfrontacyjny sposób jej odbioru i prowokowały do porównywania obu części pokazu. Owo zestawienie w opinii odbiorców wypadało na niekorzyść sztuki współczesnej. Przyczyn doszukiwano się w uległości plastyków polskich wobec wpływów „schyłkowej sztuki zachodniej" w pierwszych dziesięcioleciach XX w. W związku z tym, jak pisano, „większość polskich artystów nie tylko utraciła narodowe oblicze i łączność z postępową, narodową tradycją realistyczną, ale doszła do zupełnego upadku mistrzostwa artystycznego"28.

Interesująca jest również kwestia wspomnianych wpisów do księgi pamiątkowej i fakt przytoczenia niektórych $\mathrm{z}$ nich przez Zanozińskiego $\mathrm{w}$ „Przeglądzie Artystycznym", fachowym czasopiśmie dotyczącym spraw plastyki. Opinie zwiedzających, niejednokrotnie anonimowe, zostały uwzględnione na równi z wypowiedziami krytyków i potraktowane jako istotny głos dotyczący recepcji sztuki polskiej w ZSRR. Zwraca uwagę mentorski ton tych komentarzy, przekonanie o własnej racji i traktowanie drugiej strony jako mniej uświadomionej w dziele budowy komunizmu. Odbiorca radziecki - przedstawiciel ,światowej awangardy socjalistycznej" - poczuwał się do obowiązku wskazania plastykom polskim uchybień i możliwych dróg, a właściwie jedynej słusznej drogi do ich przezwyciężenia. Warto tu przytoczyć jedną z wypowiedzi, najpełniej odsłaniającą schemat projektowanych relacji, w których socjalistyczne - w pierwszej kolejności radzieckie - społeczeństwo oraz jego przedstawiciel - partia, występują jako główna instancja, zleceniodawca, który oczekuje od artysty pełnego zespolenia swojej postawy $\mathrm{z}$ wolą ogółu ${ }^{29}$ (w kontaktach międzynarodowych oznaczało to ideologiczną wyższość Związku Radzieckiego nad PRL-em, państwem satelickim): „Wydaje mi się - napisano w jednym z komentarzy - że współczesna sztuka polska znajduje się na niewłaściwej drodze, a właściwie chyli się ku upadkowi. Przecież należy iść do przodu, w kierunku realizmu socjalistycznego.

7 „Комсомольская правда” 1952, nr 120, cyt. za: Zanoziński, Pokłosie..., s. 45.

28 Tichomirow, Wystawa sztuki polskiej..., s. 14.

29 Рог. Екатерина Деготь, Русское искусство ХХ века, Москва 2000, s. 140. 
Irina Gavrash

Przecież polscy artyści mają od kogo się uczyć: wielkie dziedzictwo przeszłości, wielki realizm Matejki i in., sztuka Związku Radzieckiego i postanowienia KC WKP(b) dotyczące sztuki. Z tego wszystkiego należy korzystać. Miejmy nadzieję, że polscy artyści zrozumieją, na czym polegają ich błędy, które wynikają nie tyle z nieumiejętności, co być może z niezrozumienia negatywnych wpływów [prądów nowoczesnych], i pod kierunkiem najlepszych ludzi Polski, swojej partii, Bolesława Bieruta będą w stanie obrać odpowiednią drogę"30.

Podobny ton charakteryzował również wypowiedzi plastyków radzieckich, którzy zwracali uwagę na rażące różnice w poziomie sztuki dawnej i jej współczesnych reminiscencji, na hamujące czynniki w postaci pozostałości „formalizmu” i jednocześnie życzyli „młodszym kolegom” z Polski, by przezwyciężyli te ograniczenia ${ }^{31}$.

Jak już wspomniano, dział współczesny zawierał wybór prac prezentowanych wcześniej na dwóch pierwszych Ogólnopolskich Wystawach Plastyki [dalej: OWP], a także na wystawie „Plastycy w walce o pokój”. Nagrody i wyróżnienia otrzymane podczas tych ważnych dla życia artystycznego w Polsce wydarzeń nobilitowały twórcę $\mathrm{i}$ jego dzieło w ramach ówczesnego systemu artystycznego. W związku z tym nasuwają się pytania o różnice w odbiorze dzieł plastyków polskich w Polsce i w Moskwie. Dobrym przykładem może tu być praca Kobzdeja Podaj cegłę, która doczekała się niepochlebnych opinii odbiorców radzieckich. Autor jednego z wpisów do księgi pamiątkowej pyta: „Co chciał powiedzieć Kobzdej w swym obrazie Podaj cegłę? Czy pokazać złą organizację pracy? Zresztą obraz ten i namalowany jest bardzo formalistycznie, jak większość prac z ostatniego okresu. Szkoda, że współcześni artyści polscy nie wykorzystują tego pięknego dziedzictwa, które pozostawili im mistrzowie XIX stulecia. Jest to - rzecz jasna - etap przejściowy"32. Tymczasem Kobzdej otrzymał za wspomnianą pracę o uproszczonej, właściwie jednoplanowej kompozycji, III nagrodę na I OWP w 1950 r. Malarz był związany ze środowiskiem „szkoły sopockiej”33, która dążyła do pogodzenia doktryny socrealistycznej z elementami koloryzmu, nurtu silnie zakorzenionego w polskiej tradycji artystycznej. Niska ranga

30 AMSZ, Departament 1., Wydział Radziecki, w. 4, t. 32, Raport Ambasady PRL w Moskwie za miesiąc czerwiec 1952 r., k. 252.

31 AMSZ, Departament 1. Wydział Radziecki, w. 4, t. 32, Raport Ambasady PRL w Moskwie za miesiąc maj 1952 r., k. 205.

32 Zanoziński, Pokłosie..., s. 46.

33 Grupa twórców działających w ramach Państwowej Wyższej Szkoły Sztuk Plastycznych w Sopocie (1945-1954), następnie przeniesionej do Gdańska. Na temat „szkoły sopockiej” zob. m.in. Elżbieta Kal, Od akademii „in spe” w Sopocie do Akademii Sztuk Pięknych w Gdańsku [w:] Akademia Sztuk Pięknych w Gdańsku, 1945-2005: tradycja i wspótczesność [katalog wystawy], red. Wojciech Zmorzyński, Muzeum Narodowe w Gdańsku, Gdańsk 2005; Hubert Bilewicz, Szkoła sopocka: między kompromisem a konformizmem [w:] Sztuka w kręgu władzy. Materiały LVII Ogólnopolskiej Sesji Naukowej Stowarzyszenia Historyków Sztuki poświęconej pamięci Profesora Szczęsnego Dettloffa (1878-1961) w 130. rocznicę urodzin, Toruń, 13-15 listopada 2008, red. Elżbieta Pilecka, Katarzyna Kluczwajd, Warszawa 2009, s. 367-378. 
nagrody na I OWP oczywiście miała ambiwalentny charakter: $\mathrm{z}$ jednej strony świadczyła o docenieniu poczynionych przez twórcę postępów w przezwyciężaniu „nawyków formalistycznych" ${ }^{34}, \mathrm{z}$ drugiej - miała uzmysławiać ciągłe braki i mobilizować do dalszych starań. Paradoksalnie, to jednak właśnie kolorystyczna formacja artystyczna w niedługim czasie zaczęła nadawać ton sztuce polskiej. Doświadczenie socrealizmu w Polsce miało bowiem nieporównanie krótszą historię niż w ZSRR. Tam właściwie nigdy ostatecznie nie zrezygnowano z obowiązującej od 1932 r. doktryny socrealistycznej, w Polsce natomiast okres ten trwał stosunkowo krótko, umownie od 1949 do 1955 r., przy czym druga jego faza (po 1952 r.) miała już łagodny charakter ${ }^{35}$. Uwzględnienie czynnika estetycznego $\mathrm{w}$ drugim podokresie obowiązywania doktryny socrealistycznej i otwarcie jej na tradycję postimpresjonistyczną było pewnego rodzaju receptą pozwalającą na - doraźne przynajmniej - przezwyciężenie impasu w sztuce polskiej, który uwidocznił się wkrótce po I OWP.

Przyjęcie w 1949 r. socrealizmu jako jedynej metody twórczej, przypieczętowane na Zjeździe Delegatów Związku Polskich Artystów Plastyków [dalej: ZPAP] w Katowicach, doprowadziło do wyróżnienia w środowisku artystycznym grupy artystów najbardziej lojalnych wobec partii - z Włodzimierzem Zakrzewskim oraz Heleną i Juliuszem Krajewskimi na czele. Objęli oni najważniejsze stanowiska w instytucjach artystycznych realizujących wytyczne polityki kulturalnej, dostosowując jednocześnie swoją twórczość do wymogów wzorców radzieckich ${ }^{36}$. Monopolizacja życia artystycznego przez tę grupę plastyków w krótkim czasie doprowadziła do negatywnych skutków, przede wszystkim zaś do wzrostu napięcia w środowisku oraz obniżenia poziomu artystycznego dzieł. W związku z tym zaczęto szukać środków zaradczych. Pod koniec 1951 r., wkrótce po naradzie twórczej w Radzie Państwa (27-28 października), Wydział Kultury PZPR sporządził notatkę „,W sprawie sytuacji w plastyce polskiej” oraz szkolnictwie artystycznym. Winą za istniejący stan obarczono grupę Krajewskich. Zarzucano im szereg nadużyć, $w$ tym postawę oportunistyczną, nadmierne podpieranie się autorytetem władzy, faworyzowanie osób z własnego kręgu, niedopuszczanie do głosu w dyskusjach osób o odmiennych poglądach, brak głębszego namysłu nad zagadnieniami kompozycji i koloru oraz (co szczególnie istotne) powierzchowne, „błędne traktowanie socrealizmu jako maniery malarskiej, wąsko określanej, a nie postawy ideologicznej twórcy, któremu w ramach tej postawy pozostawia się swobodę środków"37. Oczywiście przerzucenie całej odpowiedzialności

34 I Ogólnopolska Wystawa Plastyki 1950, „Przegląd Artystyczny” 1950, nr 3-4, s. 18-19; por. Janusz Bogucki, Sztuka Polski Ludowej, Warszawa 1983, s. 75.

35 Włodarczyk, Socrealistyczny epizod..., s. 67.

36 Juliusz Krajewski stanął na czele Zarządu Głównego ZPAP, a Helena Krajewska została redaktorką naczelną zreorganizowanego „Przeglądu Artystycznego”, odtąd głównej trybuny realizmu socjalistycznego, zob. Bogucki, Sztuka Polski Ludowej..., s. 58.

37 AAN, Wydział Kultury KC PZPR, sygn. 70, Notatka w sprawie sytuacji w plastyce polskiej, k. 6; Barbara Fijałkowska, Polityka i twórcy (1948-1959), Warszawa 1985, s. 230. 
Irina Gavrash za zaistniałą sytuację na grupę Krajewskich było zabiegiem politycznym, mającym na celu neutralizację jej rosnących ambicjii ${ }^{38}$, a jednocześnie rehabilitację i ocieplenie wizerunku partii w oczach środowiska artystycznego, które było cennym sojusznikiem w procesie stabilizacji władzy. Niemniej jednak dokument ten (a zwłaszcza przytoczony zapis) stał się brzemienny w skutkach dla dalszej ewolucji socrealizmu w Polsce. W praktyce oznaczało to możliwość poszerzenia dotychczasowego wokabularza wizualnego, z którego mogli korzystać twórcy, o nowe środki malarskie, a mianowicie o elementy koloryzmu. Recepcja języka o proweniencji postimpresjonistycznej w ramach doktryny stanowiła czynnik nobilitujący współczesną produkcję artystyczną, mocujący ją w tradycji, bo jak pisano w dokumencie: „Zaletą kapistów była wielka kultura malarska, znajomość malarstwa obcego i na ogół wysoka wrażliwość artystyczna, zwłaszcza na sprawy koloru" ${ }^{39}$. Wkrótce tendencje te ujawniły się ze szczególną mocą i na kolejnych OWP większość nagród została rozdysponowana pomiędzy przedstawicieli koloryzmu i jego socrealistycznych mutacji ${ }^{40}$.

Zmiany w polskim życiu artystycznym miały również wpływ na selekcję eksponatów przeznaczonych na wystawę w Moskwie. Włączono do niej m.in. obraz Przy książce $e^{41}$ Eugeniusza Eibischa, czołowego przedstawiciela koloryzmu, który po naradzie w 1951 r. pretendował do zajęcia miejsca po Krajewskich (oni także brali udział w pokazie $)^{42}$. Uwzględniono również prace kolejnych przedstawicieli „szkoły sopockiej” - obok wspomnianego już obrazu Kobzdeja na wystawie znalazły się: Gertruda Wysocka - przodowniczka pracy Juliusza Studnickiego (III nagroda na wystawie „Plastycy w walce o pokój”), W chłopskiej chacie Stanisława Teysseire' ${ }^{43}$, Po rekordowym załadunku Kazimierza Śramkiewicza (II nagroda na wystawie „Plastycy w walce o pokój”), a także wielkoformatowe dzieło będące owocem pracy kolektywu plastyków z sopockiej uczelni, a zarazem pierwszą „manifestacją wspólnoty artystycznej”44 - Demonstracja 1-majowa w Warszawie w 1905 r., znana też pod tytułem Dzierżyński na czele demonstracji na placu Bankowym ${ }^{45}$. Kompozycja ta, budząca powszechne zainteresowanie zwiedzających w dziale sztuki współczesnej, chociażby ze względu na duże gabaryty, ale też wielofigurową kompozycję realizująca nośny temat, nie uniknęła jednak zarzutów o schematyzm rozumiany jako pochodna wpływów „formalizmu” ${ }^{\prime \prime}$.

38 Włodarczyk, Socrealistyczny epizod..., s. 67.

39 AAN, Wydział Kultury KC PZPR, sygn. 70, Notatka w sprawie sytuacji w plastyce polskiej, k. 6.

Bogucki, Sztuka Polski Ludowej..., s. 79.

${ }^{41}$ W katalogu I OWP zob. Wieś czyta: II Ogólnopolska Wystawa Plastyki..., s. 22, nr kat. 55.

42 Włodarczyk, Socrealistyczny epizod..., s. 67.

3 W katalogu I OWP zob. W zagrodzie: II Ogólnopolska Wystawa Plastyki..., s. 33, nr kat. 282.

4 Bilewicz, Szkoła Sopocka..., s. 369-370.

45 Autorzy: Juliusz Studnicki [szkic], Krystyna Łada-Studnicka, Stanisław Teysseire, Jacek i Hanna Żuławscy, Teresa Pągowska, Józefa Wnukowa i Jan Wodyński.

${ }_{46}$ Zanoziński, Pokłosie..., s. 46. Zob. także: AMSZ, Departament 1., Wydział Radziecki, w. 4, t. 32, Raport Ambasady PRL w Moskwie za miesiąc czerwiec 1952 r., k. 256. 
Zdaje się, że dobór eksponatów do działu współczesnego, wynikający ze swoistego rozłożenia akcentów w polskiej polityce kulturalnej, mógł stanowić świadomą strategię władz PRL-u, które miały na celu przeforsowanie w ZSRR postawy przyjętej wobec spraw sztuki. W związku z poszerzeniem formuły malarstwa socrealistycznego o elementy modernizmu zrozumiała staje się również decyzja o pokazaniu w ramach działu retrospektywnego dzieł takich artystów, jak Władysław Podkowiński (Mokra wieś, 1892), Olga Boznańska (m.in. Dwie dziewczynki, 1896) czy Ferdynand Ruszczyc (Ziemia, 1898). Jednak wobec dogmatycznej definicji metody twórczej obowiązującej w ZSRR, zgodnie z którą socrealizm miał opierać się na asymilacji schedy dziewiętnastowiecznej z wyłączeniem wszelkich wpływów sztuki nowoczesnej, od impresjonizmu poczynając (przynajmniej w teorii), konflikt ze stroną radziecką był właściwie $\mathrm{w}$ tę prezentację wpisany.

Kolejne nieporozumienia między obydwoma środowiskami artystycznymi ujawniły się w doborze delegacji polskiej, która została zaproszona do Moskwy z okazji otwarcia wystawy. Oprócz wymienionych już Sokorskiego, Zanozińskiego oraz Wnuka (współtworzącego w pierwszych latach powojennych środowisko sopockie, a od 1951 r. piastującego stanowisko rektora warszawskiej ASP) do Moskwy pojechali Aleksander Kobzdej oraz Adam Smolana, obaj związani z PWSSP w Sopocie, a także Karol Ferster, Jan Marcin Szancer, Janusz Bogucki oraz niewymieniony z nazwiska przedstawiciel Ministerstwa Kultury i Sztuki ${ }^{47}$. Zdziwienie w kręgach twórców radzieckich wywołała nieobecność wśród delegacji artystów biorących udział w ekspozycji, wyjątek stanowił tu Kobzdej.

Grupa artystów polskich, przebywająca w Moskwie od 5 maja do 16 czerwca $1952 \mathrm{r}^{48}$, miała czas, by poznać życie artystyczne w stolicy ZSRR. Członkowie delegacji odwiedzili ważniejsze ośrodki radzieckiego szkolnictwa artystycznego, m.in. Instytut Sztuk Pięknych im. W.I. Surikowa i Moskiewski Instytut Sztuki Stosowanej, a także pracownie plastyków radzieckich ${ }^{49}$. Dzięki staraniom ambasady Wnuk i Smolana wzięli udział w organizowanej przez Akademię Sztuk Pięknych ZSRR konferencji poświęconej zagadnieniom rzeźby monumentalnej (28-30 maja $)^{50}$. Osobnym punktem w programie pobytu delegacji polskiej było zwiedzanie Galerii Trietiakowskiej, gdzie artyści mieli okazję obejrzeć dzieła dawnej sztuki rosyjskiej na ekspozycji stałej oraz prace plastyków

47 AAN, KWKZ, sygn. 9, Sprawozdanie KWKZ za 2. kwartał 1952 r., k. 59.

$48 \quad \mathrm{Z}$ przerwą na pobyt w Leningradzie (1 czerwca - ?).

49 AMSZ, Raport Ambasady PRL w Moskwie za miesiąc maj 1952 r., s. 199. Polacy spotkali się z twórcami radzieckimi - malarzami i grafikami: Nikołajem Żukowym, Pawłem Sokołowym-Skalią, Kukryniksami (Michaił Kuprijanow, Porfiry Kryłow, Nikołaj Sokołow), Jewgienijem Kibryką, oraz rzeźbiarzem Nikołajem Tomskim, zob. AMSZ, Departament 1. Wydział Radziecki, w. 4, t. 32, Raport Ambasady PRL w Moskwie za miesiąc maj 1952 r., k. 199.

50 Zob. Вопросы развития советской скульптуры (Материаль конференции, 28-30 мая 1952 года), Москва 1953. 
Irina Gavrash

współczesnych zebrane na Wszechzwiązkowej Wystawie Plastyki za $1951 \mathrm{r}$. (20 grudnia 1951 - 26 maja 1952), którą właśnie ze względu na wizytę gości z Warszawy przedłużono o kilka dni ${ }^{51}$.

Jednak próby nawiązania kontaktu między polskim i radzieckim środowiskiem okazały się nieudane. Prawdopodobnie pod koniec pobytu grupy polskiej w Moskwie zorganizowano spotkanie w Ambasadzie PRL, na którym zjawili się tylko nieliczni czołowi przedstawiciele radzieckiego świata artystycznego (m.in. Gierasimow i Manizer), i to głównie ze względu na piastowane przez nich wysokie stanowiska, które obligowały do bywania na tego typu imprezach. W zbiorach Archiwum MSZ znalazły się raporty Ambasady PRL w Moskwie, w których informowała ona o przyjęciu wystawy przez środowisko radzieckie i o przebiegu wizyty delegacji polskiej. Jak wynika z notatek, podziw artystów polskich wzbudziły stosowane w radzieckich szkołach artystycznych metody nauczania oraz wysoki poziom przygotowania studentów. Jednak już wyniki tego kształcenia w postaci gotowej produkcji artystycznej, prezentowanej w salach Galerii Trietiakowskiej ${ }^{52}$ (oraz w kilku innych punktach miasta ze względu na dużą liczbę eksponowanych prac ${ }^{53}$ ), zostały przyjęte dużo chłodniej, wyżej oceniono jedynie grafikę radziecką ${ }^{54}$.

Z pewnością spotkania polskich artystów z radzieckimi kolegami (oraz zwiedzanie ekspozycji) zostały pomyślane jako element programu dydaktycznego. Zakładano, że delegacja powinna poznać życie artystyczne Związku Radzieckiego, aby przejąć wzory i wykorzystać je w organizacji systemu artystycznego w Polsce ${ }^{55}$. Jednak, jak wynika $\mathrm{z}$ relacji ambasady, realizacja tego schematu odbiegała od odgórnie założonego planu.

W oficjalnych kontaktach artystycznych ze Związkiem Radzieckim należy wyodrębnić dwa poziomy - składanych przez obydwie strony deklaracji

51 AMSZ, Departament 1., Wydział Radziecki, w. 4, t. 32, Raport Ambasady PRL w Moskwie za miesiąc maj 1952 r., k. 199.

52 Recenzja z wystawy zamieszczona w „Iskusstwie” 1952, nr 1, głównym czasopiśmie poświęconym sprawom plastyki w ZSRR, została przedrukowana w „Przeglądzie Artystycznym”, zob. Doroczny bilans (Na marginesie Wszechzwiazkowej Wystawy Plastyki 1951), „Przegląd Artystyczny" 1952, nr 3, s. 44-57. Praktyka przedrukowywania omówień wystaw radzieckich w czasopismach polskich stanowiła jeden z elementów transponowania wzorców radzieckich do Polski.

53 Na ekspozycji pokazano 1231 prac autorstwa 641 eksponentów. Filie wystawy zostały otwarte w salach Moskiewskiego Towarzystwa Artystów (29 grudnia 1951 r.) oraz Pałacu Kultury Zakładów im. I.A. Lichaczewa (26 stycznia 1952 r.).

http://www.maslovka.org/modules.php?name=Content\&pa=showpage\&pid=1409\&p age $=21$ [dostęp: 15.07.2018].

54 AMSZ, Departament 1., Wydział Radziecki, w. 4, t. 32, Raport Ambasady PRL w Moskwie za miesiąc maj 1952 r., k. 236.

55 W dniu 15 lipca w Zarządzie Koła TPPR przy ZPAP w Warszawie odbyło się zebranie, w którym uczestniczyli członkowie delegacji polskiej: Szancer, Kobzdej oraz Ferster. Złożyli oni sprawozdanie - stanowiące stały, niejako obligatoryjny element wymiany osobowej z ZSRR - z wyjazdu oraz z przyjęcia wystawy sztuki polskiej w Moskwie, zob. „Trybuna Ludu” 1952, nr 198, s. 3. Zob. także: Polskie życie artystyczne..., s. 123. 
i faktycznej realizacji obopólnych zobowiązań. Obie te sfery nie zawsze pokrywały się ze sobą, często dochodziło do pęknięć, nawet w czasach surowego stalinizmu, o czym świadczy recepcja wystawy w $1952 \mathrm{r}$. Owe szczeliny pogłębiły się „100 lat jeszcze bardziej w następnych latach, zwłaszcza w okresie odwilży, kiedy liberalizacja życia politycznego i kulturalnego osiągnęła znacznie większe natężenie w Polsce niż w ZSRR. Wówczas zapewnieniom o wzajemnym pogłębianiu więzi artystycznych towarzyszyło w praktyce ich zamrożenie. O tym, na ile relacje artystyczne były uwikłane w politykę i nosiły fasadowy charakter, może świadczyć zestawienie sprawozdań przygotowanych przez Ambasadę PRL w Moskwie o charakterze poufnym (ujawniających napięcia w kontaktach środowisk twórczych) oraz oficjalnych wypowiedzi, skierowanych do szerokiego grona odbiorców. Udzielając wywiadu korespondentowi TASS, centralnej agencji prasowej ZSRR, Marian Wnuk, kierownik delegacji w 1952 r. ${ }^{56}$, dobierał już słowa znacznie uważniej niż w kuluarowych dyskusjach z przedstawicielami ambasady. Przedrukowana w polskiej prasie wypowiedź artysty została sformułowana w duchu oficjalnej retoryki tamtych czasów: „Podczas pobytu w ZSRR - przekonaliśmy się, że ludzie radzieccy pracują w imię szczęścia człowieka, w imię pokoju na całym świecie. Przekonaliśmy się, że plastyka radziecka powiązana jest ściśle z narodem. Doszedłem do wniosku, że plastyka radziecka jest najlepszym przykładem dla artystów polskich" ${ }^{\prime 57}$. To z pewnością zdania, które mają charakter wyuczonej, sztucznej formuły.

$\mathrm{Z}$ drugiej strony, co jest również wymowne, Aleksander Kobzdej, którego wrażenia z podróży zostały opublikowane w kraju, omawiając wizyty w głównych muzeach radzieckich - moskiewskiej Galerii Tretiakowskiej oraz leningradzkim Ermitażu - skupił się na dawnym malarstwie rosyjskim i europejskim, ani słowem nie wspominając o współczesnej sztuce radzieckiej. Zajmowała go raczej spuścizna twórców takich, jak Andriej Rublow, Wasilij Surikow czy Ilja Riepin, oraz mistrzów europejskich, takich jak Tycjan, Leonardo da Vinci, Paolo Veronese czy Rembrandt. O „dobrodziejstwach” nowego systemu mówił przede wszystkim w aspekcie wysiłku dźwignięcia się kraju ze zniszczeń wojennych i dołożenia starań w sprawie ochrony spuścizny artystycznej oraz upowszechniania jej wśród społeczeństwa ${ }^{58}$.

Wojciech Włodarczyk, pisząc o cenzurze dzielącej okres socrealizmu w sztuce polskiej na dwa podokresy, zaznaczał, że zmiana, która zaszła w 1952 r., wiązała się także z umocnieniem pozycji osób skupionych wokół Juliusza Starzyńskiego, prezentujących w badaniach nad sztuką nurt tradycyjny ${ }^{59}$. Skupienie uwagi badawczej nad sztuką dawną mogło stanowić świadomą strategię

56 Warto jednak dodać, że faktyczną opiekę nad grupą po wyjeździe wiceministra Sokorskiego do kraju przejął przedstawiciel MKiS Kulik, zob. AMSZ, Departament 1., Wydział Radziecki, w. 4, t. 32, Raport Ambasady PRL w Moskwie za miesiąc maj 1952 r., k. 199.

57 „Trybuna Ludu” 1950, nr 167, s. 1.

58 Aleksander Kobzdej, Z wycieczki plastyków polskich do ZSRR, „Wola Ludu” 1952, nr 167, s. 4.

59 Włodarczyk, Socrealistyczny epizod..., s. 67. 
Irina „przetrwania”, wycofania się w mniej zideologizowaną przestrzeń. Zapewne Gavrash podobny zabieg zastosował Kobzdej, przemilczając sprawy plastyki współczesnej w ZSRR i koncentrując się przede wszystkim na bogactwie dorobku artystycznego minionych stuleci.

Przegląd sztuki polskiej w Moskwie, który miał stanowić pewnego rodzaju sprawdzian dla strony polskiej, ujawnił rozdźwięk w pojmowaniu zadań plastyki w obydwu krajach, który w kolejnych latach - mimo politycznej dominacji ZSRR - wciąż się pogłębiał. Przyzwolenie na większą swobodę formalną, udzielone plastykom przez decydentów polityki kulturalnej w Polsce, było działaniem czysto pragmatycznym. Dawało narzędzia do ocieplania wizerunku władzy i pozyskiwania przychylności środowiska artystycznego, a to z kolei postrzegano jako czynnik stabilizujący władzę w kraju. Oczywiście o porzuceniu obowiązującej metody twórczej nie można było jeszcze w owym czasie mówić. Dopiero śmierć Stalina uruchomiła procesy, które stworzyły sprzyjające ku temu warunki.

\section{Bibliografia}

Bilewicz Hubert, Szkoła sopocka: między kompromisem a konformizmem [w:] Sztuka w kręgu władzy. Materiały LVII Ogólnopolskiej Sesji Naukowej Stowarzyszenia Historyków Sztuki poświęconej pamięci Profesora Szczęsnego Dettloffa (1878-1961) w 130. rocznicę urodzin, Toruń, 13-15 listopada 2008, red. Elżbieta Pilecka, Katarzyna Kluczwajd, Warszawa 2009, s. 367-378.

Bogucki Janusz, Sztuka Polski Ludowej, Warszawa 1983.

Doroczny bilans (Na marginesie Wszechzwiązkowej Wystawy Plastyki 1951), „Przegląd Artystyczny" 1952, nr 3, s. 44-57.

Fijałkowska Barbara, Polityka i twórcy (1948-1959), Warszawa 1985.

Golon Mirosław, Między stalinowska propaganda a upowszechnianiem kultury. Działalność Wszechzwiązkowego Towarzystwa Łączności Kulturalnej z Zagranica (WOKS) wobec Polski w latach 1945-1956, „Dzieje Najnowsze” 2006, R. 37, nr 4, s. 123-145.

Kal Elżbieta, Od akademii „in spe” w Sopocie do Akademii Sztuk Pięknych w Gdańsku [w:] Akademia Sztuk Pięknych w Gdańsku, 1945-2005: tradycja i współczesność [katalog wystawy], red. Wojciech Zmorzyński, Muzeum Narodowe w Gdańsku, Gdańsk 2005, s. 14-103.

Kobzdej Aleksander, Z wycieczki plastyków polskich do ZSRR, „Wola Ludu” 1952, nr 167, s. 4.

Ogólnopolska Wystawa „Plastycy w walce o pokój” [katalog wystawy], Centralne Biuro Wystaw Artystycznych „Zachęta”, Warszawa 1950.

I Ogólnopolska Wystawa Plastyki 1950, „Przegląd Artystyczny” 1950, nr 3-4, s. 11-22.

I Ogólnopolska Wystawa Plastyki [katalog wystawy], Muzeum Narodowe w Warszawie, Warszawa 1950.

II Ogólnopolska Wystawa Plastyki [katalog wystawy], Centralne Biuro Wystaw Artystycznych „Zachęta”, Warszawa 1951.

Polskie Życie Artystyczne w latach 1944-1960, t. 6, Rok 1952, red. Anna Wiszniewska, Warszawa 2015. 
Tichomirow Aleksander, Wystawa sztuki polskiej, „Przegląd Artystyczny” 1952, nr 3, s. 7-14.

„Trybuna Ludu” 1950, nr 167, s. 1.

„Trybuna Ludu” 1952, nr 198, s. 3.

Włodarczyk Wojciech, Socrealistyczny epizod [w:] Warszawa-Moskwa / МоскваВариава. 1900-2000 [katalog wystawy], red. Maria Poprzęcka, Lidja Jowlewa, Narodowa Galeria Sztuki „Zachęta”, Warszawa 2005, s. 63-69.

Włodarczyk Wojciech, Socrealizm. Sztuka polska 1950-1954, Kraków 1991.

Zanoziński Jerzy, Pokłosie wystawy plastyki polskiej w Moskwie, „Przegląd Artystyczny” 1952, nr 4, s. 43-46.

„Вечерняя Москва” 1952, nr 129, cyt. za: Jerzy Zanoziński, Pokłosie wystawy plastyki polskiej w Moskwie, „Przegląd Artystyczny” 1952, nr 4, s. 44.

Вопросы развития советской скульптуры (Материалы конференизи, 28-30 мая 1952 года), Москва 1953.

Выставка польского изобразительного искусства [katalog wystawy], Москва 1952.

Голомшток Игорь, Тоталитарное искусство, Москва 1994.

Деготь Екатерина, Русское искусство ХХ века, Москва 2000.

Занозиньский Ежи, Выставка польского искусства [w:] Выставка польского изобразительного искусства [katalog шуstawy], Москва 1952, s. 6-17.

„Комсомольская правда” 1952, nr 120, cyt. za: Jerzy Zanoziński, Pokłosie wystawy plastyki polskiej w Moskwie, „Przegląd Artystyczny” 1952, nr 4, s. 45.

Сокорский Влодзимеж [w:] Выставка польского изобразительного искусства [katalog wystawy], Москва 1952, s. 4-5.

Филиал выставки польского изобразительного искусства. Плакат [katalog wystawy], Москва 1952.

Exhibition „100 years of realism in Polish art” at the Academy of Fine Arts of the USSR in Moscow (1952) in the context of Polish-Soviet cultural relations in years 1949-1955

The article analyses the exhibition named „100 lat realizmu w sztuce polskiej” [100 Years of Realism in Polish Art] at the Academy of Fine Arts in Moscow in 1952 and its reception in the artistic environment of USSR in the context of Polish-Soviet artistic relations in 1949-1955. The exposition, prepared by the Committee of the International Cultural Cooperation with and the Ministry of Culture and Art, consisted of the Polish art of the $19^{\text {th }}$ century and the art of a few previous years. It was supposed to present to the Soviet party the progress of the implementation of Socialist Realism in Poland on the basis of the Soviet example and Polish tradition of realistic art. However, the implementation of the scheme deviated from the official declarations due to both including in the exhibition the turn of the century, as well as presenting the issues of modernism and the selection of modern pieces, resulting from the specific emphases in the cultural policy of the time. The contemporary department was composed of pieces of artists from the 'Sopot School', combining in its art the Socialist Realism doctrine with elements of colourism. Opening the method onto elements of the Impressionism tradition was dictated by a need to break the deadlock which the Polish art found itself in soon after 
Irina the $1^{\text {st }}$ OWP. The exhibition caused a reaction in the environment of Soviet critics and Gavrash artists, exposing differences in attitude towards art in the two countries, which, in the conditions of the political dominance of USSR, had been deepened further with time, impinging on the artistic relations dynamics. 